\title{
Maternal undernutrition during lactation leads to reduction in skull size and thickness of adult-aged Wistar rats
}

\author{
Lucas A.S. Pires ${ }^{1,2}$, Albino Fonseca Junior ${ }^{1,2}$, Carlos A.A. Chagas ${ }^{1}$, Jorge H.M. Manaia ${ }^{1,2}$, \\ Vinicius S. Gameiro' ${ }^{2}$, Marcio A. Babinski ${ }^{1,2}$
}

${ }^{1}$ Fluminense Federal University, Niterói, Rio de Janeiro, Brazil

${ }^{2}$ Medical Sciences Post Graduation Program, Fluminense Federal University, Niterói, Rio de Janeiro, Brazil

Submitted: 9 March 2018; Accepted: 5 July 2018

Online publication: 19 January 2020

Arch Med Sci 2021; 17 (4): 1093-1099

DOI: https://doi.org/10.5114/aoms.2020.92433

Copyright $\odot 2020$ Termedia \& Banach

\section{Abstract}

Introduction: It is known that the quality and quantity of milk is directly related to the dietary habits of the mother. Despite that, the rates of maternal malnutrition during lactation are increasing in several countries; thus, observing its effects on the offspring is relevant. The present study aims to verify the effects of maternal malnutrition during breastfeeding on the skulls of adult-aged Wistar rats.

Material and methods: Thirty-six newborn rats were divided in three groups: the control group, in which the mother received a regular commercial diet containing $23 \%$ protein in unlimited amounts; the protein-energy restriction group, in which the dam received a commercial diet containing $8 \%$ protein in unlimited amounts; the energy restricted group, in which the dam received a commercial diet containing $23 \%$ of protein in limited amounts. After weaning, all rats received the same diet as the control group until 180 days of age. Then, the rats were euthanized, and their crania were excised and measured in radiographic images. Afterwards, their skull was decalcified with nitric acid (5\%) and histological samples were obtained and the thickness of the diploe was verified. Descriptive statistics and ANOVA followed by the Newman-Keuls test were performed for comparison purposes.

Results: It was observed that the skull from the protein-energy restriction and energy-restriction groups was smaller and thinner than that of the control group in several parameters.

Conclusions: Maternal malnutrition during the lactation period caused longterm effects in skull morphology of Wistar rats. These effects could not be reversed after regulation of the diet.

Key words: maternal malnutrition, skull, Wistar rat, histology, morphometrics, breastfeeding.

\section{Introduction}

Malnutrition is characterized as poor ingestion of essential nutrients that are necessary for health maintenance. This is caused either by famine or poor dietary habits [1, 2].

Breastfeeding is essential for the correct development of the newborn and it brings benefits to the mother as well. However, proper dietary

\author{
Corresponding author: \\ Prof. Lucas A.S. Pires \\ Fluminense Federal University \\ Niterói \\ Rio de Janeiro, Brazil \\ E-mail: lucaspires@id.uff.br
}


habits are essential for both the pregnant and lactating mother $[3,4]$.

Despite that, maternal malnutrition rates are still fairly high among the general population. Hence, it is still a public health issue in developing or underdeveloped countries [5-7].

An inadequate amount of micronutrients is one of the main causes of maternal malnutrition in low income countries - essentially due to the lack of resources [5]. On the other hand, cultural factors and myths regarding the mother's diet during the lactation period are another cause of nutrient restriction [6].

Several studies have proposed that maternal malnutrition during pregnancy [8], the lactation period [9-11] or during both timeframes [12-14] can cause several developmental changes in multiple tissues of the offspring.

Some of these studies evaluated the central nervous system (CNS) and behavioral changes [13, 14], while other studies observed changes in muscle tissue [12] and bony tissue [10, 11, 15], although regarding bones, most of these studies performed morphometric evaluations of the studied bones (e.g. femur, cranium). In addition, there are a few studies that addressed the long-term effects of bone growth on offspring whose mothers were malnourished during the lactation period $[10,11,16]$.

It is known that the development of the cranium is essential for the consolidation of the CNS. This relation is mutual, since diseases that affect the CNS often impact skull growth [17].

Thus, the study of maternal malnutrition during the lactation period and its effects on cranium development is relevant. The present study aims to analyze the skull of adult aged Wistar rats whose mothers were malnourished during the breastfeeding period.

\section{Material and methods}

The study presented herein was approved by the Animal Care and Use Committee of the State University of Rio de Janeiro (CEUA/036/2010), which based its analysis on the Guide for the Care and Use of Laboratory Animals [18].

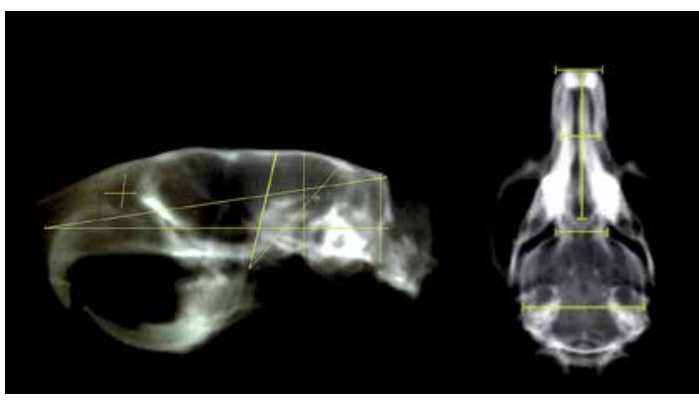

Figure 1. X-ray of the rat's skull depicting the morphometric parameters. Lateral view and superior view
Furthermore, this experiment complies with the ARRIVE guidelines and the National Institutes of Health guide for the care and use of laboratory animals (NIH Publications No. 8023, revised 1978).

Six healthy adult female Wistar rats gave birth to a significant number of healthy pups. After birth, the progenitors were divided into three groups with two dams each: a protein-energy restricted group (PER), which received in unlimited amounts a commercial diet containing $8 \%$ protein; an energy restricted group (ER), which received a commercial diet containing $23 \%$ protein in limited amounts, according to the amount ingested by the PER group; and a control group (C), in which the progenitors received unlimited amounts of a commercial diet with $23 \%$ protein.

The dams' malnourishment started on day 0 of the experiment (immediately post-partum) throughout the lactation period (21 days). Six male pups were assigned to each dam, in order to maximize breastfeeding potential [10], totaling 12 pups per group.

After weaning, the pups were randomly placed in cages in groups of three. All pups received the same commercial diet (23\% of protein) until adult age $\left(180^{\text {th }}\right.$ day). Then, the rats were euthanized with a lethal dose of thiopental and their cranium was excised and fixed in a $10 \%$ formalin solution.

The skulls were weighed and X-rays were obtained for measurement purposes (Figure 1). Morphometric parameters were previously defined by Fernandes et al. [9] (Table I).

Afterwards, the skulls were routinely decalcified in a solution of $5 \%$ nitric acid and histological samples were obtained (hematoxylin/eosin stain was used). The thickness of the diploe was measured in four different anatomical landmarks (nasion, vertex, bregma and inion) with the Image J software. Five random measurements were performed in five random fields (40× magnification) in all skulls and expressed as millimeters ( $\mathrm{mm}$ ) (Figure 2). The lacunae were examined in five random fields of the cortical bone (100x magnification) from each region and expressed as percentage (ratio of empty lacuna number to the total lacuna count) and their

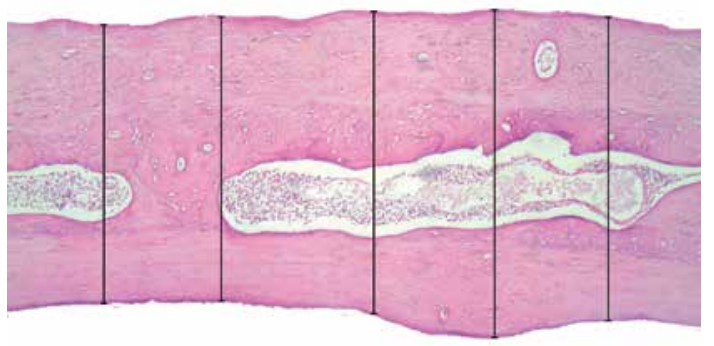

Figure 2. Measurement of the diploe thickness (40x $H \& E)$ 
Table I. Parameters used in the morphometric analysis according to Fernandes et al. (2008)

\begin{tabular}{|c|c|}
\hline Parameter & Definition \\
\hline Height $1(\mathrm{H} 1)$ & $\begin{array}{l}\text { Maximum height of the neurocranium (occipital level of the braincase) = distance between } \\
\text { the uppermost tip of the external occipital crest and the level of the occipital foramen (border) }\end{array}$ \\
\hline Height $2(\mathrm{H} 2)$ & $\begin{array}{l}\text { Maximum height of the neurocranium (parietal level of the braincase) }=\text { distance between } \\
\text { the anteromedial edge of the right tympanic bulla and the most dorsoventral surface of the skull }\end{array}$ \\
\hline Height 3 (H3) & $\begin{array}{c}\text { Maximum height of the orbital cavity }=\text { distance between the right upper and lower walls } \\
\text { of the orbit - level of the infraorbital fissure }\end{array}$ \\
\hline Height $4(\mathrm{H} 4)$ & $\begin{array}{c}\text { Maximum height of the neurocranium (fronto-parietal level of the braincase) = distance } \\
\text { between the posterior nasal spine (posterior palatine extremity) and the union point } \\
\text { of the coronal and sagittal sutures }\end{array}$ \\
\hline Heigh & $\begin{array}{c}\text { Maximum height of the neurocranium (parieto-occipital level of the braincase) = distance } \\
\text { between the posterior nasal spine (posterior palatine extremity) and the union } \\
\text { of the lambdoid and sagittal sutures }\end{array}$ \\
\hline Length 1 (L1) & $\begin{array}{l}\text { Maximum length of the neurocranium (rectangular measurement) = distance between } \\
\text { the external occipital protuberance and the alveolar margin of the incisive bone }\end{array}$ \\
\hline Length 2 (L2) & $\begin{array}{l}\text { Maximum length of the dorsoventral neurocranium (linear measurement) = distance } \\
\text { between the external occipital protuberance and the alveolar margin of the incisive bone }\end{array}$ \\
\hline Length 3 (L3) & $\begin{array}{c}\text { Maximum length of the basal neurocranium (linear measurement) = distance } \\
\text { between the most ventral aspect of the foramen occipital and the alveolar margin } \\
\text { of the incisive bone in the median plane }\end{array}$ \\
\hline Length 4 (L4) & $\begin{array}{l}\text { Maximum length of the nasal bone = anterior tip of nasal bone - suture between the nasal } \\
\text { and frontal bone in the median plane }\end{array}$ \\
\hline Length 5 (L5) & $\begin{array}{l}\text { Maximum length of the palatine bone = distance between the posterior nasal spine } \\
\text { (posterior palatine extremity) and the alveolar margin of the incisive bone in the median plane }\end{array}$ \\
\hline Length 6 (L6) & $\begin{array}{l}\text { Maximum length of the sphenoid bone = distance between the most ventral aspect of the foramen } \\
\text { magnum and the posterior nasal spine (posterior palatine extremity) in the median plane }\end{array}$ \\
\hline Length 7 (L7) & $\begin{array}{c}\text { Maximum length of the orbital cavity }=\text { distance between the most ventral aspect } \\
\text { of the right infraorbital and supraorbital margin }\end{array}$ \\
\hline Width 1 (W1) & $\begin{array}{l}\text { Nasal width = distance between the right margin of the nasomaxillary suture (level of the medial } \\
\text { infraorbital border) }- \text { the left margin of the nasomaxillary suture }\end{array}$ \\
\hline Width 2 (W2) & $\begin{array}{l}\text { Premaxillary width = distance between the rightmost lateral aspect of the premaxillary, medial } \\
\text { infraorbital border - the leftmost lateral aspect of the premaxillary, medial infraorbital border }\end{array}$ \\
\hline Width 3 (W3) & $\begin{array}{l}\text { Frontal width = distance between the rightmost constricted region of the frontal (temporal line, } \\
\text { level of the zygomatic-malar process suture) - the leftmost constricted region of the frontal }\end{array}$ \\
\hline Width 4 (W4) & $\begin{array}{l}\text { Distance between the tympanic bulla = anteromedial edge of the right tympanic bulla - } \\
\text { anteromedial edge of the left tympanic bulla }\end{array}$ \\
\hline
\end{tabular}

mean area was measured (expressed in $\mu \mathrm{m}$ ) and analyzed.

\section{Statistical analysis}

Statistical analysis was performed with the aid of the IBM SPSS statistical software. The data presented here are reported as mean \pm standard deviation (SD). Statistical significance was evaluated by one-way analysis of variance (ANOVA) followed by the Newman-Keuls test to compare the three groups ( $p<0.05$ was considered significant).

\section{Results}

\section{Macroscopic analysis}

The mean weight of the crania was $9 \mathrm{~g}, 8 \mathrm{~g}$ and $7 \mathrm{~g}$ in the C, ER and PER groups, respectively. These values were not statistically significant $(p>0.05)$.
The $\mathrm{H} 1, \mathrm{H} 2, \mathrm{H} 3, \mathrm{H} 4$ and $\mathrm{H} 5$ values were significantly reduced in the PER group in comparison to the $C$ group $(p<0.05)$. However, when the $C$ and ER or the PER and ER groups were compared, most of these values did not have a statistical significant difference. This also was observed in the W1, W2, W3, L3, L4 and L7 measurements.

These measurements are covered in detail in Table II and Figure 3.

\section{Microscopic analysis}

It was observed on the histological images that the PER and ER group had more empty lacunae on the cortical bone than the $\mathrm{C}$ group (Figure 4). Rates of empty lacuna on the C, ER and PER groups were $7.65 \pm 2.23 \%, 8.36 \pm 3.67 \%$, and $10.41 \pm 2.91 \%(p>0.05)$, respectively. Histomorphometric analysis of the lacunae showed 
Lucas A.S. Pires, Albino Fonseca Junior, Carlos A.A. Chagas, Jorge H.M. Manaia, Vinicius S. Gameiro, Marcio A. Babinski

Table II. Morphometric results of the skull in the adult-aged rats (mean \pm SD of 12 pups per group)

\begin{tabular}{|c|c|c|c|c|c|c|}
\hline \multirow{2}{*}{$\begin{array}{l}\text { Parameter } \\
{[\mathrm{mm}]}\end{array}$} & \multicolumn{3}{|c|}{ Groups } & \multicolumn{3}{|c|}{$P$-value } \\
\hline & $\mathrm{C}$ & ER & PER & C vs. ER & C vs. PER & ER vs. PER \\
\hline Height 1 & $12.49 \pm 0.42$ & $12.17 \pm 0.29$ & $11.29 \pm 0.38$ & $>0.05$ & $<0.05$ & $<0.05$ \\
\hline Height 2 & $14.93 \pm 0.59$ & $14.70 \pm 0.28$ & $14.29 \pm 0.38$ & $>0.05$ & $<0.05$ & $<0.05$ \\
\hline Height 3 & $4.97 \pm 0.32$ & $4.58 \pm 0.22$ & $4.49 \pm 0.25$ & $<0.05$ & $<0.05$ & $>0.05$ \\
\hline Height 4 & $13.49 \pm 0.37$ & $13.29 \pm 0.34$ & $13.02 \pm 0.60$ & $>0.05$ & $<0.05$ & $>0.05$ \\
\hline Height 5 & $18.03 \pm 0.58$ & $17.70 \pm 0.40$ & $17.10 \pm 0.70$ & $>0.05$ & $<0.05$ & $>0.05$ \\
\hline Length 1 & $48.06 \pm 1.37$ & $47.52 \pm 1.05$ & $47.43 \pm 0.99$ & $>0.05$ & $>0.05$ & $>0.05$ \\
\hline Length 2 & $47.81 \pm 1.45$ & $47.17 \pm 1.00$ & $47.14 \pm 0.95$ & $>0.05$ & $>0.05$ & $>0.05$ \\
\hline Length 3 & $45.79 \pm 1.37$ & $44.91 \pm 1.03$ & $44.74 \pm 1.06$ & $<0.05$ & $<0.05$ & $>0.05$ \\
\hline Length 4 & $19.64 \pm 0.71$ & $19.04 \pm 0.83$ & $18.83 \pm 0.46$ & $>0.05$ & $<0.05$ & $>0.05$ \\
\hline Length 5 & $26.92 \pm 0.79$ & $26.59 \pm 0.61$ & $26.47 \pm 0.52$ & $>0.05$ & $>0.05$ & $>0.05$ \\
\hline Length 6 & $27.04 \pm 0.81$ & $26.72 \pm 0.59$ & $26.73 \pm 0.54$ & $>0.05$ & $>0.05$ & $>0.05$ \\
\hline Length 7 & $6.25 \pm 0.31$ & $5.85 \pm 0.35$ & $5.59 \pm 0.22$ & $<0.05$ & $<0.05$ & $>0.05$ \\
\hline Width 1 & $4.48 \pm 0.19$ & $4.38 \pm 0.22$ & $4.17 \pm 0.22$ & $>0.05$ & $<0.05$ & $>0.05$ \\
\hline Width 2 & $8.03 \pm 0.23$ & $7.69 \pm 0.16$ & $7.61 \pm 0.13$ & $<0.05$ & $<0.05$ & $>0.05$ \\
\hline Width 3 & $7.40 \pm 0.19$ & $7.25 \pm 0.21$ & $7.09 \pm 0.22$ & $>0.05$ & $<0.05$ & $>0.05$ \\
\hline Width 4 & $17.06 \pm 0.41$ & $17.16 \pm 0.25$ & $17.00 \pm 0.34$ & $>0.05$ & $>0.05$ & $>0.05$ \\
\hline
\end{tabular}

$C$ - control group, ER - energy restricted group, $P E R$ - protein-energy restricted group. $P<0.05$ is considered significant.

A

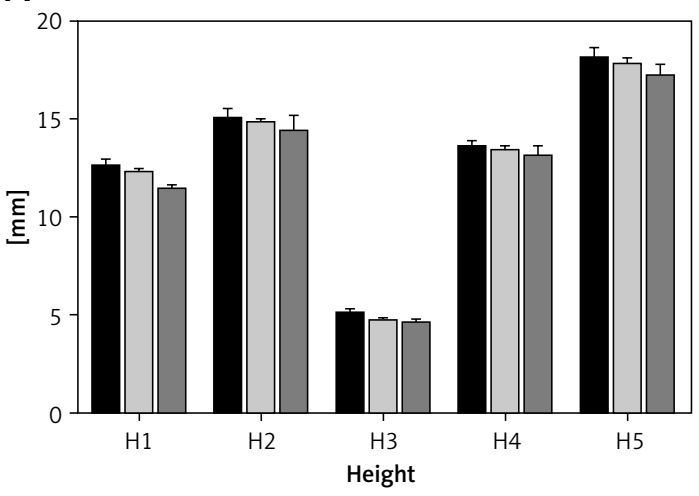

B

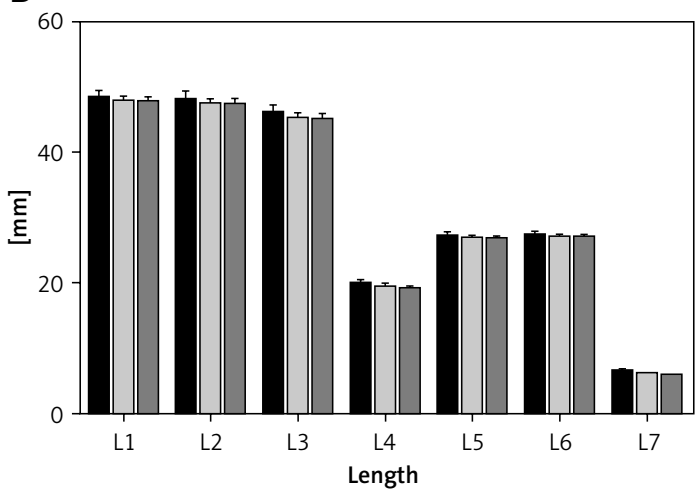

C

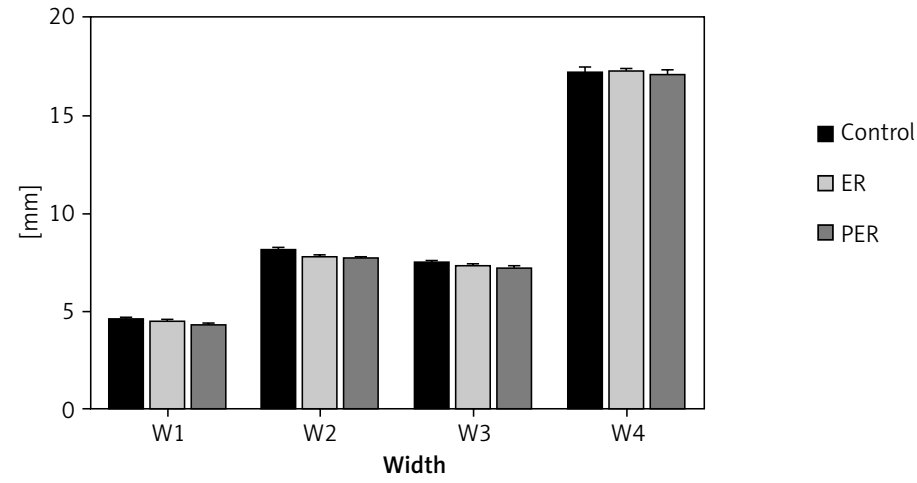

Figure 3. Graphic showing the macroscopic morphometric results (mean and standard deviation) of the three groups. $\mathrm{H}$ - height, L - length, $\mathrm{W}$ - width 

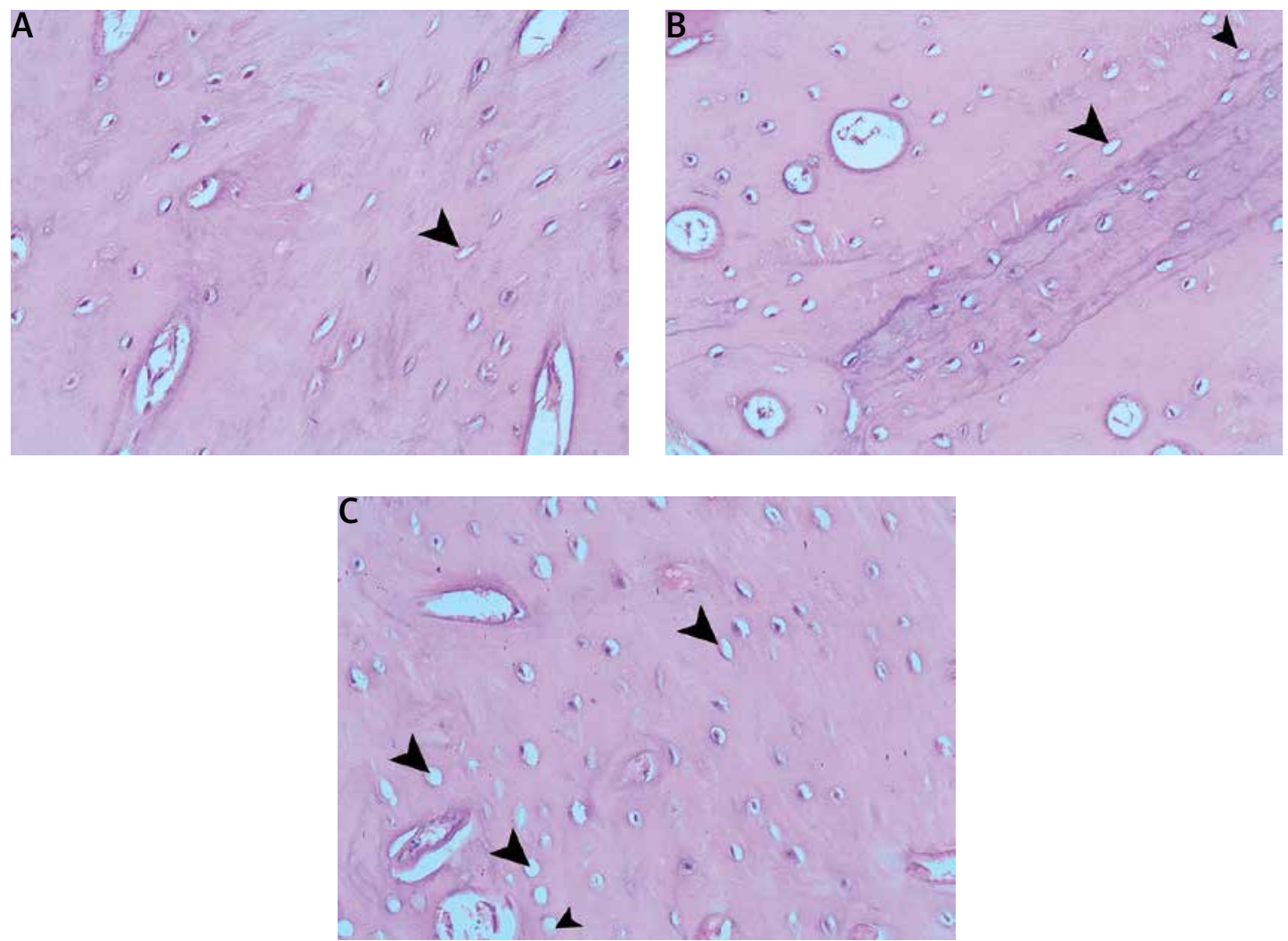

Figure 4. Histological findings of the lacunae of the control (A), energy restricted (B) and protein-energy restriction (C) groups. A higher number of empty lacunae (black arrowheads) can be observed in the protein-energy restriction group (C). 200×/H\&E

a mean area of $6.72 \pm 3.23 \mu \mathrm{m}, 8.13 \pm 2.81 \mu \mathrm{m}$ and $9.54 \pm 3.77 \mu \mathrm{m}$ on the C, ER and PER groups respectively $(p>0.05)$.

Regarding skull thickness, there was a statistically significant difference of the vertex between the three groups $(p<0.05)$. In addition, there were statistically significant differences between the $C$ and PER groups regarding the bregma, nasion and vertex regions $(p<0.05)$. Detailed measurements of each region can be observed in Table III and Figure 5.

\section{Discussion}

The breastfeeding period is essential for the correct development of the newborn as it benefits multiple systems of the organism. It is known that the mother's diet directly affects the quality and quantity of the produced milk. Despite that, there are significant rates of maternal malnutrition in developing and developed countries [1, 2, 4-6, 19].

The effects of maternal malnutrition during pregnancy have been intensively studied in the literature. These studies have proven the metabolic imprinting (or fetal programming) theory, in which the effects caused during the intra-uterine life may induce metabolic disturbances in later periods [19-24].
However, recent studies have shown that the lactation period is also a critical window for inducing developmental changes in several tissues. Thus, metabolic imprinting may occur up until the end of the breastfeeding period [7, 9-12, 14-16, 25].

The present study showed that the skull in the PER group was significantly smaller than in $C$ or ER groups. Moreover, the diploe was significantly thinner in the PER group in two anatomical landmarks. Thus, there was observed a negative impact in skull growth caused by maternal protein-energy restriction during the lactation period.

Despite the methodological differences, the results presented herein are similar to the studies performed by Ramirez Rozzi et al. [26] and Luna et al. [15], as there were significant alterations in the crania size of the malnourished groups.

Catch-up growth is considered as the compensatory growth during the recovery window after growth restriction. It can be complete (type A) when the animal reaches normal adult size, or incomplete (type B) when it fails to reach the regular growth curve. The concept of catch-up growth was well explained by Boersma and Wit [27].

Much is known about catch-up growth; however, there is uncertainty whether catch-up growth is possible or not as there is a mosaic of different 
Table III. Diploe thickness of the three groups (mean \pm SD of 12 pups per group)

\begin{tabular}{|lcccccc|}
\hline $\begin{array}{l}\text { Thickness } \\
{[\mathrm{mm}]}\end{array}$ & \multicolumn{3}{c}{ Groups } & & \multicolumn{2}{c|}{$P$-value } \\
\cline { 2 - 7 } & C & ER & PER & C vs. ER & C vs. PER & ER vs. PER \\
\hline Bregma & $0.30 \pm 0.03$ & $0.29 \pm 0.04$ & $0.27 \pm 0.02$ & $>0.05$ & $<0.05$ & $<0.05$ \\
\hline Inion & $0.37 \pm 0.01$ & $0.37 \pm 0.04$ & $0.35 \pm 0.04$ & $>0.05$ & $>0.05$ & $>0.05$ \\
\hline Nasion & $0.34 \pm 0.04$ & $0.32 \pm 0.03$ & $0.32 \pm 0.01$ & $<0.05$ & $<0.05$ & $>0.05$ \\
\hline Vertex & $0.26 \pm 0.03$ & $0.24 \pm 0.02$ & $0.21 \pm 0.05$ & $<0.05$ & $<0.05$ & $<0.05$ \\
\hline
\end{tabular}

$C$ - control group, ER - energy restricted group, $P E R$ - protein-energy restricted group. $P<0.05$ is considered significant.

A

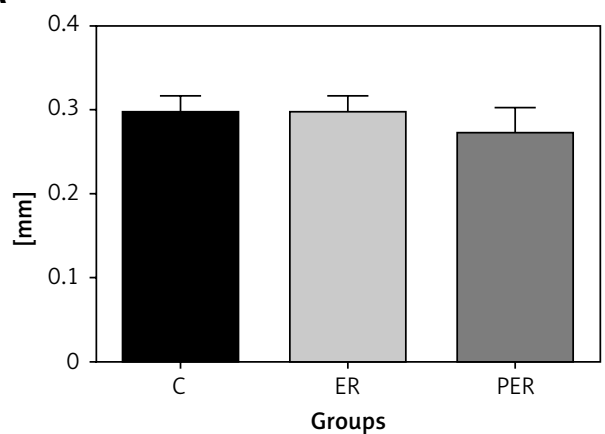

C

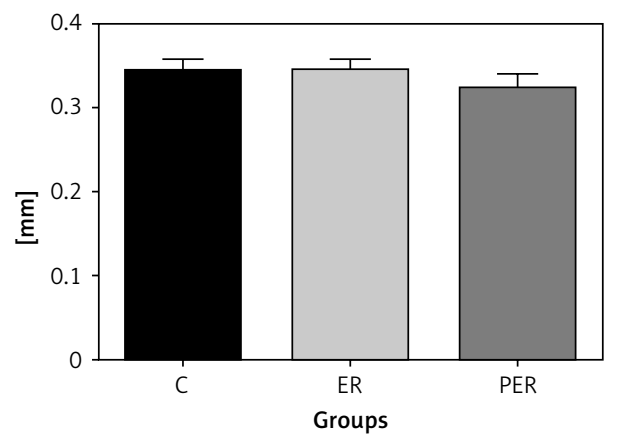

B

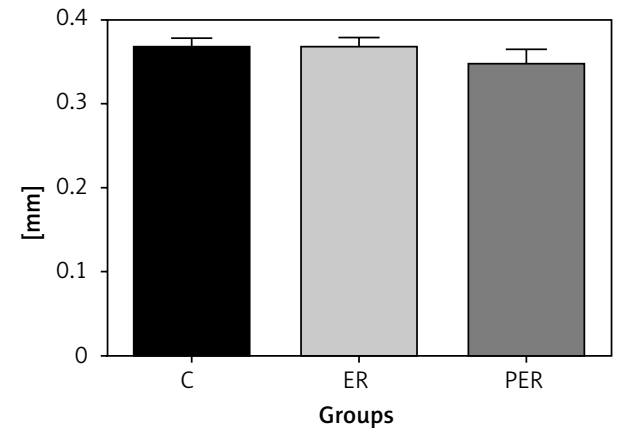

D

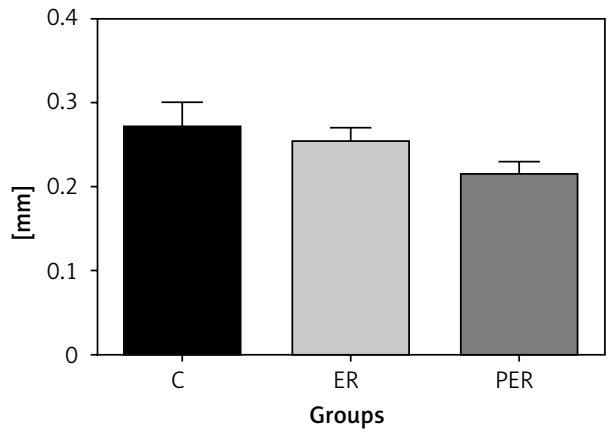

Figure 5. Graphic showing the histomorphometric results (mean and standard deviation) of the bregma (A), inion (B), nasion (C), and vertex (D) of the three groups

results in the literature, especially when both periods (pregnancy and breastfeeding) are considered separately [10, 11, 25, 28].

In the present study, catch-up growth is considered as the period in which the skull growth of the rats from the PER and ER groups would take to reach the skull growth of the $C$ group. A previous study performed by Fernandes et al. [9] observed similar results to ours, albeit in young rats. When their results are compared to the ones presented herein, it is clear that catch-up growth was not possible since these changes in skull growth continued even after regular dietary intake of the adult aged rats.

Furthermore, a slightly higher percentage of empty lacunae could be observed in the ER and PER groups. Although they were not statistically significant, these results may indicate that there is in- deed an injury of bony tissue caused by maternal malnutrition during the lactation phase.

The study of the lacunae which surrounds the osteocyte is used to measure pathological changes on bony tissue caused by osteoporosis; for instance, thus, it can be a predictor of abnormalities within the bone [29, 30].

Moreover, conditions such as premature synostosis can cause impairment of CNS development; in addition, diseases of the CNS (such as Zika) can impact skull growth as well since their ontogenic process is closely related and mutually dependent [17].

In this fashion, our results might indicate that the changes in skull growth are associated with neurological alterations of the PER groups observed in the studies performed by Belluscio et al. [13] and Natt et al. [14]. 
In conclusion, the study presented herein revealed that there were several changes in the skul and the diploe of rats whose dams were malnourished during the breastfeeding period. The results of this study also showed that these changes could not be reversed even after regular dietary intake between the weaning period and the adult age, thus concluding that catch-up growth was not possible.

\section{Conflict of interest}

The authors declare no conflict of interest.

\section{References}

1. Ahasan S, Mansoori N, Mohiuddin SM, Mubeen SM, Saleem R, Irfanullah M. Frequency and determinants of malnutrition in children aged between 6 to 59 months in district Tharparkar, a rural area of Sindh. J Pak Med Assoc 2017; 67: 1369-73.

2. Kavle JA, Mehanna S, Khan G, Hassan M, Saleh G, Engmann C. Program considerations for integration of nutrition and family planning: beliefs around maternal diet and breastfeeding within the context of the nutrition transition in Egypt. Matern Child Nutr 2018; 14: e12469.

3. Plećas D, Plesinac S, Kontić Vucinić O. Nutrition in pregnancy: basic principles and recommendations. Srp Arh Celok Lek 2014; 142: 125-30.

4. Ares Segura S, Arena Ansótegui J, Díaz-Gómez NM; Comité de Lactancia Materna de la Asociación Española de Pediatría. The importance of maternal nutrition during breastfeeding: do breastfeeding mothers need nutritional supplements? An Pediatr (Barc) 2016; 84: 347.e1-e7.

5. Haileslassie K, Mulugeta A, Girma M. Feeding practices, nutritional status and associated factors of lactating women in Samre Woreda, South Eastern Zone of Tigray, Ethiopia. Nutr J 2013; 12: 28.

6. Jeong G, Park SW, Lee YK, Ko SY, Shin SM. Maternal food restrictions during breastfeeding. Korean J Pediatr 2017; 60: 70-6.

7. Victora CG, Bahl R, Barros AJD, et al. Breastfeeding in the $21^{\text {st }}$ century: epidemiology, mechanisms, and lifelong effect. Lancet 2016; 387: 475-90.

8. Schatten H, Constantinescu GM (eds.). Animal Models and Human Reproduction: Cell and Molecular Approaches with Reference to Human Reproduction. $1^{\text {st }}$ ed. John Wiley \& Sons, Canada 2007.

9. Fernandes RM, Abreu AV, Silva RB, et al. Maternal malnutrition during lactation reduces skull growth in weaned rat pups: experimental and morphometric investigation. Anat Sci Int 2008; 83: 123-30.

10. Babinski MSD, Ramos CF, Fernandes RMP, Cardoso GP, Babinski MA. Maternal malnutrition diet during lactation period leads to incomplete catch-up growth in femur of the pups at adulthood. Int J Morphol 2016; 34: 71-7.

11. Schultz G, Medeiros F, Arcoverde M, et al. Chronic effects of maternal malnutrition during lactation: severe influences on cortical bone mass of wistar rats femur. J Clin Diagn Res 2017; 11: RC05-08.

12. Confortim HD, Jeronimo LC, Centenaro LA, Pinheiro PF, Matheus SM, Torrejais MM. Maternal protein restriction during pregnancy and lactation affects the development of muscle fibers and neuromuscular junctions in rats. Muscle Nerve 2017; 55: 109-15.
13. Belluscio LM, Berardino BG, Ferroni NM, Ceruti JM, Canepa ET. Early protein malnutrition negatively impacts physical growth and neurological reflexes and evokes anxiety and depressive-like behaviors. Physiol Behav 2014; 129: 237-54.

14. Natt D, Barchiesi R, Murad J, et al. Perinatal malnutrition leads to sexually dimorphic behavioral responses with associated epigenetic changes in the mouse brain. Sci Rep 2017; 7: 11082.

15. Luna M, Quintero F, Cesani M, et al. Craneofacial effect of prenatal growth retardation and postnatal undernutrition in craniofacial growth. Rev Arg Antrop Biol 2016; 18. doi: 10.17139/raab.2016.0018.01.04

16. Fernandes RMP, Abreu AV, Schanaider A, et al. Effects of protein and energy restricted diet during lactation leads to persistent morphological changes on tibia growth in the weaned pups. Int J Morphol 2007; 25: 565-71.

17. Nunes ML, Carlini CR, Marinowic D, et al. Microcephaly and Zika virus: a clinical and epidemiological analysis of the current outbreak in Brazil. J Pediatr (Rio J) 2016; 92: 230-40.

18. Bayne K. Revised guide for the care and use of laboratory animals available. American Physiological Society. Physiologist 1996; 39: 199, 208-11.

19. Rajendram R, Preedy VR, Patel V (eds.). Diet, Nutrition, and Fetal Programming. $1^{\text {st }}$ ed. Humana Press, 2017.

20. Barker DJ. Sir Richard Doll Lecture. Developmental origins of chronic disease. Public Health 2012; 126: 185-9.

21. Barker DJ. In utero programming of cardiovascular disease. Theriogenology 2000; 53: 555-74.

22. Lee S, You YA, Kwon EJ, Jung SC, Jo I, Kim YJ. Maternal food restriction during pregnancy and lactation adversely affect hepatic growth and lipid metabolism in threeweek-old rat offspring. Int J Mol Sci 2016; 17: E2115.

23. Kumar A, Sharma S, Kar P, et al. Impact of maternal nutrition in hepatitis $\mathrm{E}$ infection in pregnancy. Arch Gynecol Obstet 2017; 296: 885-95.

24. Hyde NK, Brennan-Olsen SL, Bennett K, Moloney DJ, Pasco JA. Maternal nutrition during pregnancy: intake of nutrients important for bone health. Matern Child Health J 2017; 21: 845-51.

25. Qasem RJ, Li J, Tang HM, Pontiggia L, D'Mello AP. Maternal protein restriction during pregnancy and lactation alters central leptin signalling, increases food intake, and decreases bone mass in 1 year old rat offspring. Clin Exp Pharmacol Physiol 2016; 43: 494-502.

26. Ramirez Rozzi FV, Gonzalez-Jose R, Pucciarelli HM. Cranial growth in normal and low-protein-fed Saimiri. An environmental heterochrony. J Hum Evol 2005; 49: 515-35.

27. Boersma B, Wit JM. Catch-up growth. Endocrine Rev 1997; 18: 646-61.

28. Alippi RM, Meta MD, Boyer PM, Bozzini CE. Catch-up in mandibular growth after short-term dietary protein restriction in rats during the post-weaning period. Eur J Oral Sci 1999; 107: 260-4.

29. Bai R, Feng W, Liu WL, et al. Roles of osteocyte apoptosis in steroid-induced avascular necrosis of the femoral head. Genet Mol Res 2016; 15; doi: 10.4238/ gmr.15017529.

30. van Oers RF, Wang H, Bacabac RG. Osteocyte shape and mechanical loading. Curr Osteoporos Rep 2015; 13: 61-6. 